Chirurgia (2019) 114: 451-460

No. 4, July - August

Copyright $\odot$ Celsius

http://dx.doi.org/10.21614/chirurgia.114.4.451

\title{
Electrical Stimulation as an Alternative Treatment in Gastroesophageal Reflux Disease - Clinical Study
}

\author{
Sergiu Ungureanu', Natalia Sipitco ${ }^{1}$, Vladimir Vidiborschii ${ }^{2}$, Doina Fosa ${ }^{1}$ \\ 'Department of Surgery no 4, Laboratory for Minimally Invasive Surgery, Republican Hospital, \\ State University of Medicine and Pharmacy of the Republic of Moldova \\ ${ }^{2}$ Labromed Laborator SRL Company, Chisinau, Moldova
}

Corresponding author:

Doina Fosa, MD

Nicolae Testemitanu State University

of Medicine and Pharmacy of the

Republic of Moldova, 29,

N. Testemitanu str., Chisinau

Moldova, MD-2025

E-mail: doina_liulica_a@mail.ru

\section{Abbreviations:}

LES - lower esophageal sphincter:

GEJ - gastroesophageal junction;

GERD - gastroesophageal reflux disease;

IRP - integrated relaxation pressure;

IRP4S - IRP index 4s:

HiLESPMA - High Resolution LES

Pressure Manometry Analyzer;

BMI - body mass index;

HRM - high resolution manometry.
Received: 10.07 .2019

Accepted: 06.08.2019

\section{Rezumat \\ Electrostimularea sfincterului esofagian inferior ca tratament alternativ al bolii de reflux gastroesofagian}

Recent, a fost descrisă posibilitatea creşterii tonusului sfincterului esofagian inferior (SEI) cu ajutorul unui stimulator electric implantabil. $\mathrm{Cu}$ toate că, această metodă a fost deja utilizată în practica clinică, totuşi, parametrii optimi ai stimulării electrice a SEI nu sunt încă elucidate. Obiectivele acestui studiu au fost obținerea datelor clinice cu privire la efectele diferitelor tipuri de electrostimulare a SEI, precum şi elaborarea şi testarea prototipului de microstimulator implantabil şi încăcabil prin transfer de enrgie fără fir la animalele de laborator.

Material şi Metode: În Departamentul de Chirurgie $\mathrm{nr}$ 4, pe parcursul a 4 ani (2015-2018), a fost realizat un studiu clinicoexperimental al electrostimulării sfincterului esofagian inferior. În prima etapă, stimularea electrică a SEI a fost evaluată la 15 pacienți, utilizând un generator de impulsuri externe. Aceşti pacienți au suferit o intervenție chirurgicală antireflux, cu o inserție intraoperatorie suplimentară de 2 electrozi temporari pe SEI. Pe parcursul celei de-a doua etape, a fost creat un dispozitiv experimental care a constat dintr-un microstimulator implantabil al SEI utilizând transferul de energie fără fir. În etapa a treia, acest prototip a fost testat pe animale de laborator (porci) în centrul de chirurgie experimentală „Pius Brânzeu”, Timişoara, Romania.

Rezultate: Valorile presiunii de repaus SEI şi ale presiunii de relaxare integrată (IRP) au fost semnificativ diferite în perioadele de prestimulare şi poststimulare. 
Concluzii: S-a demonstrat cu succes posibilitatea creşterii tonusului SEI prin electrostimulare. Modificările funcționalității şi tonusului SEI, în timpul stimulării electrice şi în perioada imediată după stimulare, depind de frecvența şi intensitatea impulsului de stimulare. Este necesară modificarea suplimentară a antenei de emisie Bluetooth pentru a compensa efectul de ecranare al țesuturilor biologice.

Cuvinte cheie: sfincter esofagian inferior (SEI), stimulare electrică, boală de reflux gastroesofagian

\section{Abstract}

Background: Recently, there was described the possibility to increase the lower esophageal sphincter (LES) tone by means of implantable electrical stimulator. Although, this method has already been used in clinical practice, however, the optimal parameters of LES electrical stimulation are still unknown.

Aims: The goals of this study were to get clinical data regarding the effects of different types of electrical stimulation on LES and to elaborate and test the prototype on laboratory animals.

Material and Methods: In the Department of Surgery no 4, during 4 years (2015-2018), there has been achieved one clinical-experimental study of LES electrical stimulation. During the first stage, the electrical stimulation of the LES, using an external pulse generator, was assessed in 15 patients. These patients underwent an antireflux intervention, with an additional insertion of 2 temporary electrodes on the LES. During the second stage, there was created an experimental device which consisted of a re-insertable microstimulator using wireless energy transfer. During the third stage, it was tested in the experimental surgery center "Pius Brânzeu", Timişoara, on laboratory animals (pigs).

Results: Values of the LES resting pressure and integrated relaxation pressure (IRP) were significantly different during the prestimulation and poststimulation periods.

Conclusions: There was successfully demonstrated the possibility to increase the LES tone. Modifications in the LES functionality and tone, during the electrical stimulation and in the period immediately after the stimulation, depend upon the pulse frequency and length. Also, the additional change of the Bluetooth transmitter antenna is necessary to offset the screening effect of the biological tissues.

Key words: lower esophageal sphincter (LES), electrical stimulation, gastroesophageal reflux disease

\section{Introduction}

Laparoscopic fundoplications controlling the gastroesophageal reflux in $90 \%$ of patients, the rest of them requiring reinterventions or medical treatment.

The postoperative complications among the patients with failed surgical treatment occur in $2-6 \%$ cases, related to the change of the JEG anatomy (1). Therefore, there is a need for another minimally invasive method of treatment.
The stimulation of the gastroesophageal junction (GEJ) with an implantable device can be a physiological and reversible therapeutic method,which increases the LES tone. The GEJ electrostimulation acts on smooth muscle cells through myenteric (Auerbach) plexus. The plexus contains Cajal interstitial cells, which act as a digestive regional pacemaker by generating electrical slow waves.

The experiment has shown that a constant current, with rectangular wave and 30-500 ms duration, applied in the pacemaker node 
region, initiates the generation of slow waves and their propagation to the antrum (2). If the impulse rate is higher than natural, it becomes dominant, and the pacemaker is driven by this frequency. This phenomenon is called gastric electrical pacing, resembling to the cardiac pacing. This type of gastric stimulation induces the increase of the LES tonus, by an unclear mechanism (3).

The pacemaker in the pathology of the digestive tract has a relatively short history. The first commercially implantable device was the neuro-stimulator Enterra, produced by Medtronic Company. It was used in the treatment of gastroparesis and morbid obesity.

A similar device has been approved (EndoStim, Netherlands, 2009) for the treatment of GERD in Europe. There is a multicenter study evaluating the effectiveness of the LES electrostimulation in the treatment of gastroesophageal reflux disease (GERD), conducted by Dr. Leonardo Rodriguez in Chile (4).

Publications related to the influence of electrostimulation on the LES tone in humans are few and contradictory $(7,8,9)$.

The goal of our study was to get clinical data regarding effects of different types of electrical stimulation on LES and to elaborate and test the prototype on laboratory animals.

\section{Study Design}

We present a post hoc analysis of a prospective randomized trial, realized in a single center. The efficiency of the GEJ electrostimulation was appreciated by the increasing pressure of the LES (primary end point). The second point was to assess the preservation of the GEJ valve functionality, measured by the manometric index IRP (integrated relaxation pressure). The electrical stimulation of the LES, using an external pulse generator, was assessed in 15 patients.

By ethical considerations, we performed GEJ electrostimulation in patients with GERD who underwent standard laparoscopic surgery.

This study was approved by our University's and Republican Hospital's Research Ethics
Committee (Minutes No 2 of 11 May 2015).

During the second stage, there was created an experimental device of a re-insertable microstimulator, using wireless energy transfer. During the third stage, it was tested in the experimental surgery center "Pius Brânzeu", Timişoara, on laboratory animals (pigs).

\section{Material and Methods}

The LES stimulation with external pulse generator was assessed in 15 patients with severe GERD and decreased LES tonus. These patients were randomized in three groups of 5 patients according to the type of electrical stimulation.

The inclusion criteria were: age $>18$ years, GERD with indications for surgical treatment, duration of medical treatment $>12$ weeks, gastroesophageal reflux confirmed by 24 -hours $\mathrm{pH}$-metry (DeMeester score > 15).

Also, there were established the exclusion criteria: sliding hiatal hernia larger than $5 \mathrm{~cm}$ on preoperative radiological cliché, paraesophageal hiatal hernia, reflux esophagitis grade C and D (Los Angeles classification), GEJ stenosis, esophageal cancer, body mass index $(\mathrm{BMI})>35 \mathrm{~kg} / \mathrm{m}^{2}$, severe concomitant diseases.

All patients signed an informed consent form to participate in the clinical trial. To confirm the diagnosis of GERD, preoperatively all patients underwent gastroscopy, barium radiography and 24-hours pH-metry (Orion II, MMS, Netherlands). The day before surgery, a high resolution esophageal manometry (Solar GI HRM, MMS, Netherlands) was performed to all 15 patients. The procedure was performed after 12 hours fasting in supine position (10 water swallows with a 30 -sec period to assess basal pressure values). Patients enrolled in this study underwent laparoscopic intervention, which consisted of GEJ dissection, posterior cruroraphy and fundoplication. At the end of the intervention two temporal electrodes Flexon (Covidien, USA) were fixed to the seromuscular layer of the abdominal esophagus. The leads were sutured to the anterior part of the esophagus at a distance of at least $2 \mathrm{~cm}$ 
from each other, avoiding the vagus nerve involvement. The ends of the electrodes were exteriorized separately on the anterior abdominal wall in the epigastric region and fastened to the skin. The LES pressure and other parameters of the esophageal motility were registered by high resolution manometry (HRM) at the $3^{\text {rd }}$ postoperative day (after restoring of the digestive peristalsis).

During the manometry session, the GEJ electrical stimulation was performed with external pulse generator. Preoperative manometry data was compared to the postoperative prestimulation data, during the stimulation data and poststimulation data (Fig. 1 A, B and Fig. $2 A, B$ ). There were applied three parameter sets, the ones most commonly used in the published works for GEJ electrostimulation $(3,5,8,9)$. These sets of parameters are presented in Table 1.
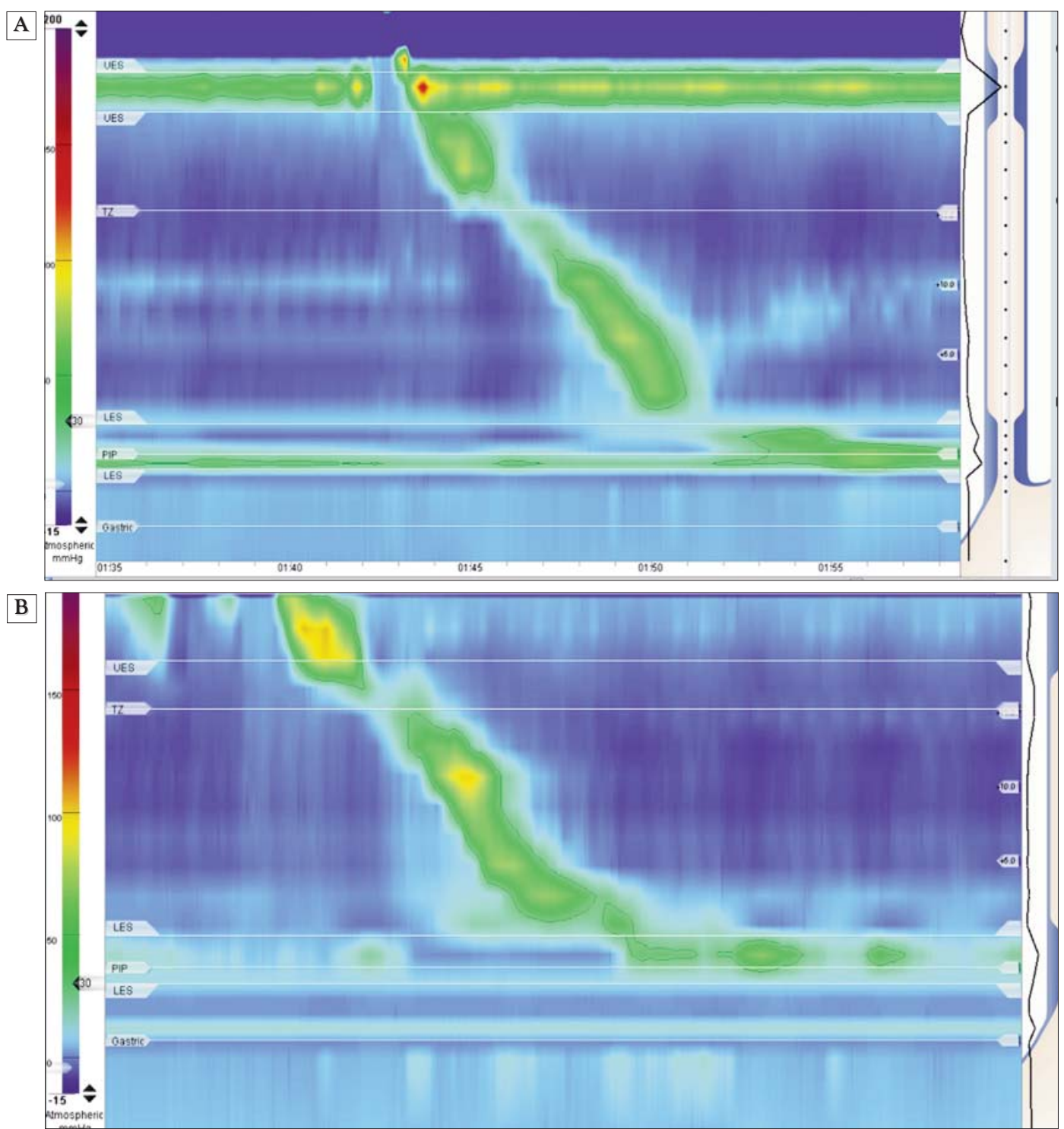

Figure $1 \mathrm{~A}, \mathrm{~B}$. Esophageal manometry in the postoperative period before electrical stimulation of the LES (A) and during the stimulation (B) (stimulation set I). (A) - absence of the LES deglutitive relaxation. (B) - the LESdeglutitive relaxation appears, maintaining the elevated pressure after the EGJ closing. Additional pressure „shadow” also appears at the level of the gastric fundoplication 

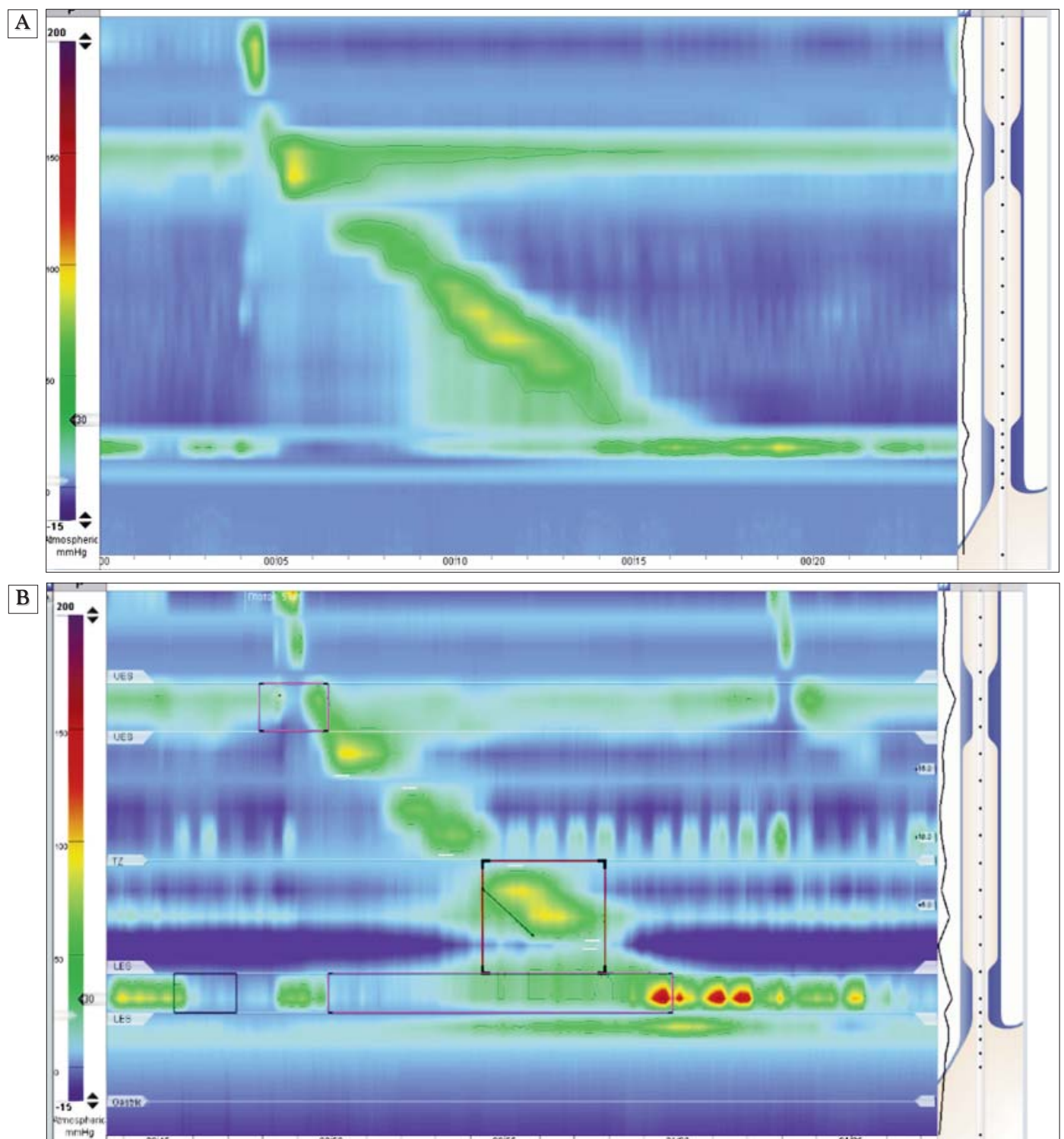

Figure 2 A, B. Manometric images in the postoperative period, before stimulation (A) and poststimiulation (B). Stimulation set II. It is observed a significant increase of the LES pressure with spastic contractions (> $100 \mathrm{mmHg}$ ), as well as an elevated pressure at this level, in the poststimulation period

Postoperative manometry was performed and the patient drank about $150 \mathrm{ml}$ of water. in three steps: prestimulation, during stimula- The multiple rapid swallow test was not tion $(25 \mathrm{~min})$, poststimulation. The duration of performed.

the procedure has not exceeded 45 minutes There were separately analyzed the mano-

Table 1. Sets of parameters used for the GEJ electrostimulation

\begin{tabular}{|c|c|c|c|c|}
\hline Parameter sets & Pulse length & Frequency & Amperage & No. ofpatients \\
\hline 1. Low-frequency, long pulse & $375 \mathrm{~ms}$ & 6 pulse/min & $5 \mathrm{~mA}$ & 5 \\
\hline 2. High-frequency $20 \mathrm{~Hz}$ & $0.3 \mathrm{~ms}$ & $20 \mathrm{~Hz}$ & $5 \mathrm{~mA}$ & 5 \\
\hline 3. High-frequency $40 \mathrm{~Hz}$ & $0.3 \mathrm{~ms}$ & $40 \mathrm{~Hz}$ & $5 \mathrm{~mA}$ & 5 \\
\hline
\end{tabular}


metric indicators that reflect the tone and functionality of the LES:

- The LES resting pressure,

- The integrated relaxation pressure with a duration of 4 seconds (IRP index $4 \mathrm{~s}$ ).

Cutoff value for IRP $4 \mathrm{~s}$ was $7 \mathrm{mmHg}$, in accordance to the study performed by Kessing, using the MMS device with a water perfused catheter (10).

The pre- and postoperative values of these indicators (pre-, during and poststimulation) were compared to each other within study groups and in the general group of 15 patients.

The electrical resistance and signal amplitude were recorded during the GEJ electrostimulation using an oscillometer ISDS205B. The electrical resistance of tissues varied within $310-415 \mathrm{Ohm}$ and the created voltage was 1-2 $\mathrm{V}$.

The electrodes were extracted at the end of the session of the postoperative manometry. The patients were under observation until the next day and then they were discharged.

The high resolution manometry data, which have been obtained during the postoperative period, was evaluated using the third version of the esophagus motility disorders Chicago classification (11).

The statistical analysis: The Wilcoxon test was used for statistical analysis for two paired samples.

During the second stage, based on the results of the clinical study, there was created the experimental device of a re-insertable microstimulator, using wireless energy transfer.

After that, it was tested in the experimental surgery center "Pius Brânzeu", Timişoara, on laboratory animals (pigs). The goal of this experiment was to evaluate the clinical efficacy of different operating modes of the prototype, during tests on laboratory animals. The clinical efficacy of the implantable pacemaker was tested during the surgical intervention, by implanting this device, with electrodes fixation on the esophagus, to a laboratory animal (pig), with subsequent measurements using the test equipment (Fig. 3). After installing the device, operational access was closed to assess

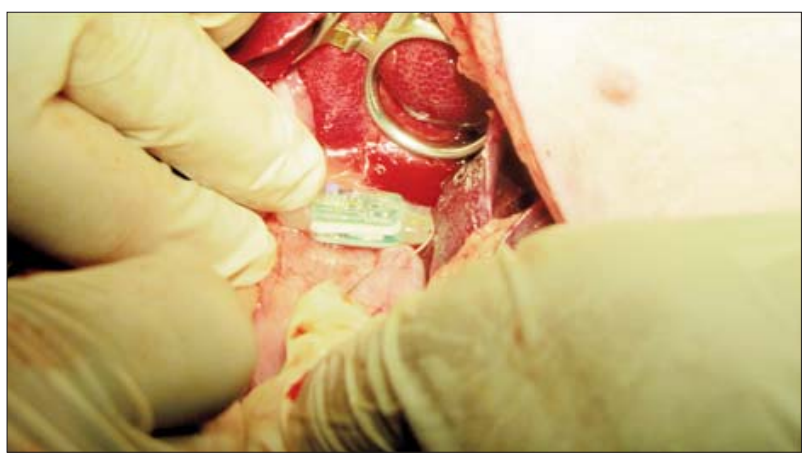

Figure 3. The re-insertablemicrostimulator, using wireless energy transfer, implanted on the esophagus of a laboratory animal

the performance of wireless communication through animal tissue. The commands and telemetry data of the installed prototype (signal power, temperature, device version) was carried out via the radio channel of the Bluetooth BLE standard using an application installed on an Android-based smartphone (Samsung Galaxy J5). To assess the electrical activity, there was made an electronic contact probe, with 3 leads and a temperature sensor. During the experiment, various operating modes of the prototype were sequentially launched, with simultaneous recording of the electrical signals, using a Siglent SHS810 oscilloscope (Fig. 4). To assess the effectiveness of the changes in the tone of the lower esophageal sphincter (LES), there was used a standard Sengstaken-Blackmore three-lumen esophageal obturator probe, which was connected,using the HiLESPMA (High Resolution LES Pressure Manometry Analyzer), to a PC (laptop) running software (Honeywell SEK002 Sensor Evaluation Kit v 4.0.0.5)(Fig. 5). The esophageal balloon was inflated with a microcompressor to a pressure of about $50 \mathrm{mmHg}$ according to a dial gauge, after which the available stimulation modes were started for the 3 available stimulation currents $(2,4$ and $6 \mathrm{~mA})$, with a simultaneous recording of the data received on a PC from a digital pressure sensor HiLESPMA device.

\section{Results}

The preoperative HRM revealed esophageal 

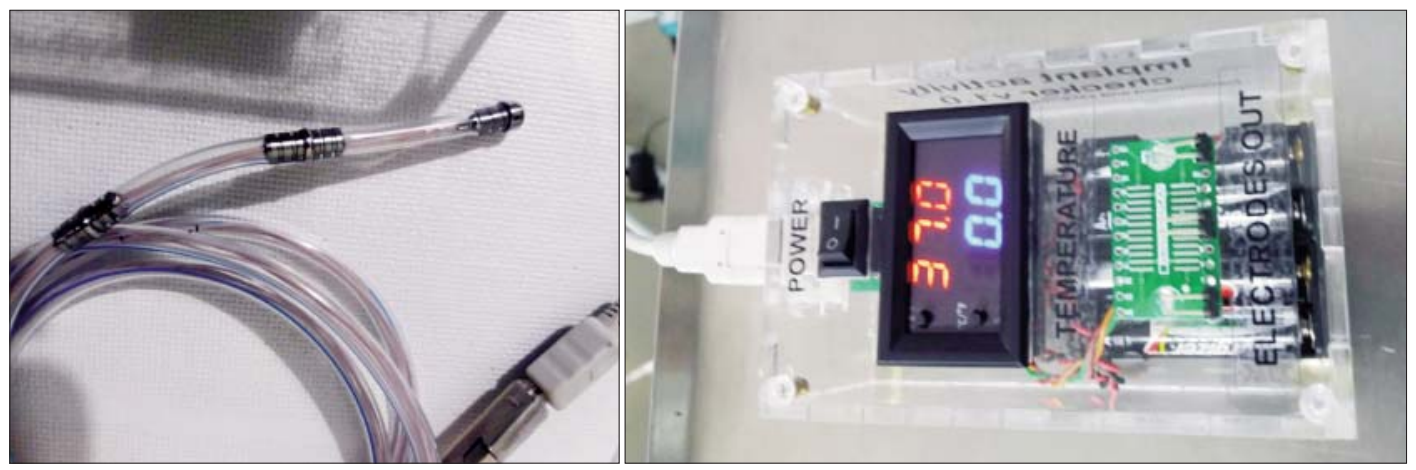

Figure 4. The evaluation probe ofthe electrical activity, temperature and implant activity checker

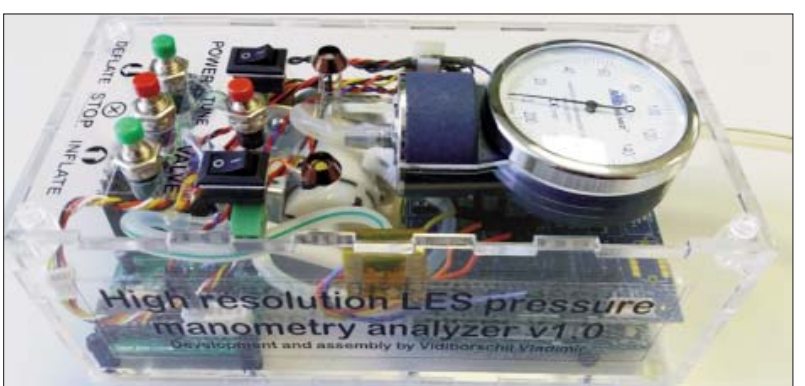

Figure 5. The high resolution LES pressure manometry analyzer HILESPMA

peristalsis disorders in the majority of patients included in the study (13 from 15 patients): there was demonstrated a fragmented peristalsis in 7 patients $(46.7 \%)$, in other $6(40 \%)-$ ineffective esophageal motility. A normal esophageal motility was registered in 2 cases (13.3\%).

Values of the LES resting pressure and IRP (during 4s) are presented in the Tables 2 and 3 respectively.

A significant difference between the preoperative and postoperative LES pressure values was established in the general group of 15 patients. As was expected, the mean values of the LES resting pressure and IRP become higher after the antireflux procedure $(p<0.01$ for each parameter, directional test).

The comparison of the mean LES resting pressure values, recorded in the postoperative period, before the LES electrical stimulation,

Table 2. Mean LES resting pressure $(\mathrm{mmHg})$

\begin{tabular}{|c|c|c|c|c|c|}
\hline Stimulation set & No. patient & Preoperative & $\begin{array}{c}\text { Postoperative } \\
\text { before stimulation }\end{array}$ & $\begin{array}{c}\text { Postoperative } \\
\text { during stimulation }\end{array}$ & $\begin{array}{l}\text { Postoperative } \\
\text { poststimulation }\end{array}$ \\
\hline \multirow[t]{5}{*}{ I } & 1 & 12.9 & 28.0 & 30.8 & 34.2 \\
\hline & 2 & 5.9 & 32.7 & 38.2 & 35.0 \\
\hline & 3 & 21.2 & 24.3 & 25.0 & 22.4 \\
\hline & 4 & 9.0 & 28.5 & 27.6 & 38.0 \\
\hline & 5 & 6.9 & 22.0 & 28.0 & 23.0 \\
\hline \multirow[t]{6}{*}{ II } & 1 & 14.2 & 38.5 & 30.4 & 118.5 \\
\hline & 2 & 11.2 & 29.3 & 27.7 & 58.9 \\
\hline & 3 & 8.9 & 34.5 & 33.0 & 47.2 \\
\hline & 4 & 6.2 & 34.3 & 38.7 & 84.5 \\
\hline & 5 & 4.2 & 33.8 & 37.3 & 57.8 \\
\hline & & & & \multicolumn{2}{|c|}{$p<0.05$} \\
\hline \multirow[t]{6}{*}{ IIII } & 1 & 13.6 & 31.0 & 30.2 & 85.4 \\
\hline & 2 & 14.6 & 25.5 & 24.2 & 39.0 \\
\hline & 3 & 22.6 & 38.3 & 32.4 & 47.3 \\
\hline & 4 & 15.2 & 53.1 & 46.8 & 88.4 \\
\hline & 5 & 5.7 & 33.5 & 50.2 & 72.3 \\
\hline & & & & \multicolumn{2}{|c|}{$p<0.05$} \\
\hline
\end{tabular}


Table 3. Mean values of IRP $4 \mathrm{~s}(\mathrm{mmHg})$

\begin{tabular}{|c|c|c|c|c|c|}
\hline Stimulation set & No. patient & Preoperative & $\begin{array}{c}\text { Postoperative } \\
\text { before stimulation }\end{array}$ & $\begin{array}{c}\text { Postoperative } \\
\text { during stimulation }\end{array}$ & $\begin{array}{c}\text { Postoperative } \\
\text { poststimulation }\end{array}$ \\
\hline & 1 & 5.7 & 14.6 & 12.2 & 13.0 \\
\hline & 2 & 5.3 & 19.1 & 14.9 & 17.6 \\
\hline & 3 & 3.4 & 7.7 & 6.7 & 6.8 \\
\hline & 4 & 8.1 & 18.8 & 12.3 & 13.2 \\
\hline & 5 & 4.4 & 8.2 & 6.7 & 6.8 \\
\hline \multicolumn{6}{|c|}{$p<0.05$} \\
\hline \multirow[t]{6}{*}{$\|$} & 1 & 6.8 & 14.5 & 13.3 & 50.1 \\
\hline & 2 & 4.5 & 12.7 & 11.4 & 31.4 \\
\hline & 3 & 2.3 & 13.8 & 11.2 & 34.5 \\
\hline & 4 & 5.6 & 18.3 & 19.5 & 24.2 \\
\hline & 5 & 3.5 & 6.3 & 8.6 & 22.4 \\
\hline & & & & $p<0.05$ & \\
\hline \multirow[t]{6}{*}{ IIII } & 1 & 4.6 & 10.5 & 18.5 & 46.2 \\
\hline & 2 & 6.4 & 12.1 & 13.1 & 17.4 \\
\hline & 3 & 10.1 & 16.7 & 14.8 & 21.4 \\
\hline & 4 & 6.5 & 19.0 & 25.8 & 44.1 \\
\hline & 5 & 3.3 & 20.1 & 26.3 & 34.4 \\
\hline & & & & $p<0.05$ & \\
\hline
\end{tabular}

and the values of this parameter in the poststimulation period, showed a significant difference with $\mathrm{p}<0.01$ for bidirectional test.

Within subgroups, the data analysis revealed some specific tendencies for each type (set) of LES stimulation. The first stimulation set produces only insignificant increase in the LES pressure during the stimulation and, at the same time, influences the deglutitive GEJ relaxation. It was manifested manometrically through normalizing of the IRP, during the stimulation, in comparison to the prestimulation values (directional test, $\mathrm{p}<0.05$ ). This parameter was elevated in the majority of patients in the postoperative period, probably due to the performed antireflux operation.

The second set of stimulation parameters produce moderate relaxation of the LES during the stimulation and significant increase of its tone in the poststimulation period $(p<0.05)$. Besides the elevation of the LES tone in the poststimulation period, this type of stimulation generates significant increase of the IRP $4 \mathrm{~s}$ - a manometric sign of the impaired deglutitive LES relaxation $(p<0.05$, in comparison to the prestimulation values). The third set of parameters show similar effects as the second stimulation set. In some patients from groups II and III, the
LES pressure reached very high values - more than $100 \mathrm{~mm} \mathrm{Hg}$ (spasm) and remained at these values throughout the examination. In these cases, patients preserved the ability to swallow; some of them manifested mild and transitory dysphagia. Complications related to the insertion and removal of the electrodes were not registered.

During the third stage, after performing the tests on laboratory animals (pigs), it should be noted that the most significant results were obtained for a $6 \mathrm{~mA}$ stimulation current (Fig. 6). It is possible that the weaker currents require modification of the type of the electrode contacting with the muscle tissue, from a point to a diffuse (for example, circular) contact. During the assessment of the tone modulation, there was recorded an increase in the tone to $+8.78 \mathrm{mmHg}$, higher background vibrations caused by breathing (Fig. 7). At the same time, the rate of pressure of the LES, in a healthy person, is about $20 \mathrm{mmHg}$, with pathology less than $10 \mathrm{mmHg}$.

\section{Discussion}

In our study model, the preoperative esophageal manometry was compared to the postoperative manometry in order to reveal and separate 


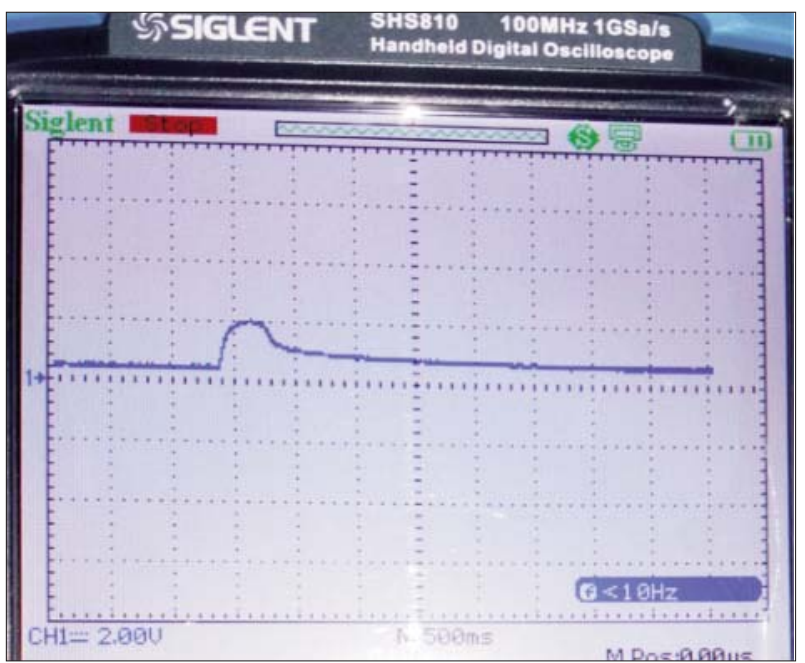

Figure 6. The registration of a microimplant stimulation pulse

modifications due to the antireflux procedure. An important characteristic of this model is the continuous recording of manometric data in the poststimulation period.

The analysis of the manometric values for the entire group of 15 patients have had demonstrated, that the LES electrical stimulation modifies the LES pressure and produces changes in the LES valve function ata current of $5 \mathrm{~mA}$. The paper published by P.W. Weijenborg tries to establish the normal manometric values for patients after surgical GERD treatment (12). The data obtained in our study, generally, corresponds to these norms. The results of the study and observed tendencies, in the groups of patients, indicate that effects of the LES electrical stimulation in humans depend upon parameters of stimulation. In our study, there were used the same current and pulse form. The most pronounced modifications of the LES tone were registered, interestingly, in the poststimulation period, and not during the stimulation. In order to obtain more precise data, a larger number of observations is necessary (10 or more patients in each group). Despite the postoperative modifications reflected by HRM, statistically significant differences were discovered in our study between LES pressure values, before and after electrical stimulation. It was also important to understand, that the rising of the LES tone, obtained by the means of the LES electrical stimulation, can be associated with the impaired relaxation of the sphincter after swallowing, which can be clinically manifested as dysphagia and even induce structural anatomical changes in case of long-term electrical stimulation. In this study the I stimulation set favorably influenced the deglutitive relaxation of the LES, although, the elevation of the LES tone was not statistically proved in this group of patients. Our data correlates with the preliminary conclusions of the multicentric study, led by L. Rodrigues, which analyzed long-term treatment of the GERD patients with an implantable device (EndoStim ${ }^{\circledR}$ ) (4). The

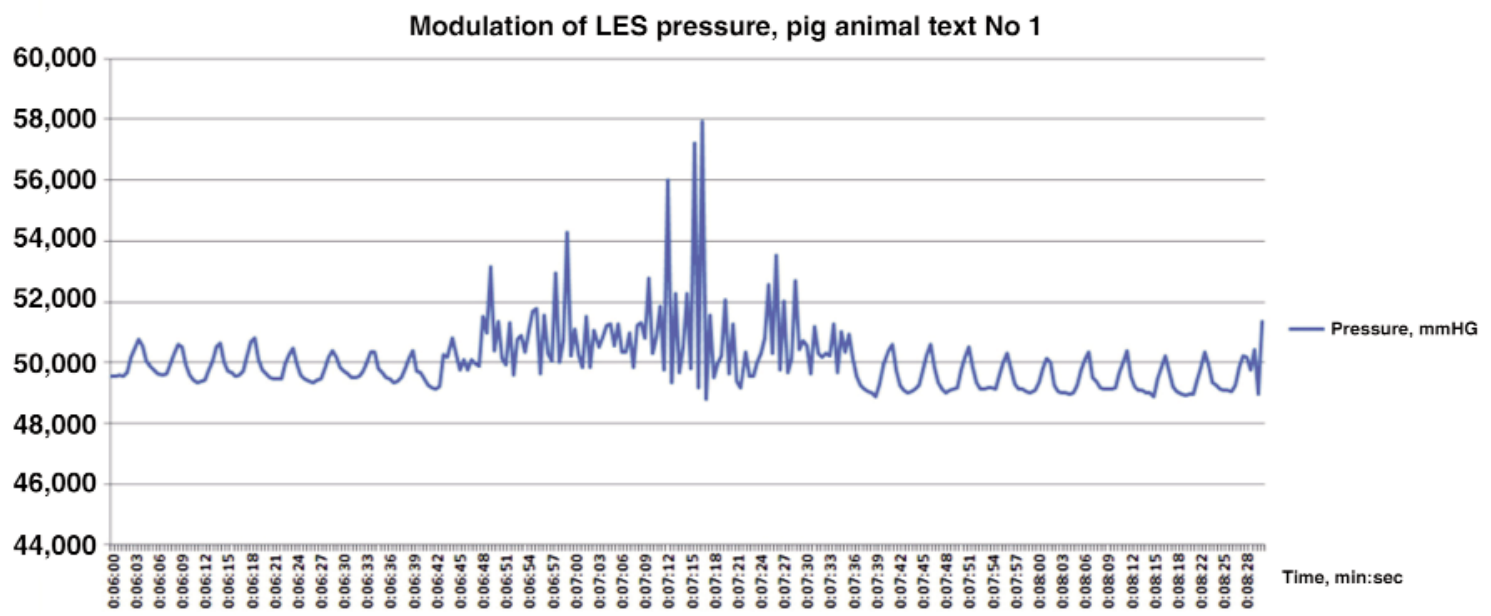

Figure 7. The registration of the modulation of the LES tone 
elaborated re-insertable microstimulator, using wireless energy transfer, successfully demonstrated the possibility of changing the tone of the LES. The most effective was the stimulation with a current of $6 \mathrm{~mA}$. The additional change of the Bluetooth transmitter antenna is necessary to offset the screening effect of the biological tissues. Taking into consideration our results we can suppose, that the use of the alternative parameters for the therapeutical LES electrical stimulation could help increase the treatment efficiency and improve patients' quality of life. Therefore, a new clinical study is needed to complete these findings.

\section{Conclusions}

Electrical stimulation modifies the LES tone. There was successfully demonstrated the possibility to increase the LES tone. Modifications of the LES functionality and tone, during the electrical stimulation, and in the period immediate after stimulation, depend upon the pulse frequency and length. The additional change of the Bluetooth transmitter antenna is necessary to offset the screening effect of the biological tissues.

\section{Conflict of Interest}

The authors declared no potential conflicts of interest with respect to the research, authorship, and/or publication of this article.

\section{References}

1. Minjarez R, Blair A. Surgical therapy for gastroesophageal reflux disease. GI Motility online. 2006, doi:10.1038/gimo56.

2. Morgan KG, Muir TC, Szurszewski JH. The electrical basis for contraction and relaxation in the canine fundal smooth muscle. J Physiol. 1981;311:475-88.

3. Xing J, Felsher J, Brody F, Soffer E. Gastric electrical stimulation significantly increases canine lower esophageal sphincter pressure. Dig Dis Sci.2005;50:1481-1487.

4. Rodriguez L, Rodriguez PA, Gomez B, Netto MG, Crowell MD, Soffer E. Electrical stimulation therapy of the lower esophageal sphincter is successful in the treating GERD: long-term 3-year results. SurgEndoscopy. 2016;30(7):2666-72.

5. Sanmiguel CP, Hagiike M, Mintchev MP, Cruz RD, Phillips EH, Cunneen SA, et al. Effect of electrical stimulation of the LES on LES pressure in a canine model. Am J Physiol Gastrointest Liver Physiol. 2008; 295:389-394.

6. Clarke JO, Jagannath SB, Kalloo AN, Long VR, Beitler DM, Kantsevoy SV. An endoscopically implantable device stimulates the lower esophageal sphincter on demand by remote control: a study using a canine model. Endoscopy. 2007;39:72-76.

7. Rodríguez L, Rodríguez P, Neto MG, Ayala JC, Saba J, Berel D, et al. Short-term electrical stimulation of the lower esophageal sphincter increases sphincter pressure in patients with gastroesophageal reflux disease. NeurogastroenterolMotil. 2012;24:446450, e213.

8. Banerjee R, Pratap N, Kalpala R, Reddy DN. Effect of electrical stimulation of the lower esophageal sphincter using endoscopically implanted temporary stimulation leads in patients with reflux disease. SurgEndosc. 2014; 28: 1003-1009.

9. Soffer E, Rodríguez L, Rodriguez P, Gómez B, Neto MG, Crowell MD. Effect of electrical stimulation of the lower esophageal sphincter in gastroesophagealreflux disease patients refractory to proton pump inhibitors. World J GastrointestPharmacolTher. 2016; $7(1): 145-55$.

10. Kessing BF, Weijenborg PW, Smout AJ, Hillenius S, Bredenoord AJ. Water-perfused esophageal high-resolution manometry; normal values and validation. Am J Physiol. 2014; 306(6):G491-5.

11. Kahrilas PJ, Bredenoord AJ, Fox M, Gyawali CP, Roman S, Smout AJ, et al. International High Resolution Manometry Working Group. The Chicago Classification of esophageal motility disorders, v3.0. NeurogastroenterolMotil. 2015;27(2):160-74.

12. Weijenborg PW, Savarino E, Kessing BF, Roman S, Constantini M, Oors JM, et al. Normal values of esophageal motility after antireflux surgery; a study using high-resolution manometry. Neurogastroenterol Motil. 2015; 27(7):929-35.

13. Krouchev NI, Danner SM, Vinet A, Rattay F, Sawan M. Energyoptimal electrical-stimulation pulses shaped by the Least-Action Principle. PLoS One.2014;9(3):e90480.

14. Hajer J, Novák M, Rosina J. Wirelessly powered endoscopically implantable devices into the submucosa as the possible treatment of gastroesophageal reflux disease. Gastroenterol Res Pract. 2019 ;2019:7459457. 